\title{
Egy mintaterület talajának variabilitása a sófelhalmozódás tényezői szerint
}

\author{
TÓTH TIBOR és VÁRALLYAY GYÖRGY
}

MTA Talajtani és Agrokémiai Kutatóintézet, Budapest

A jelen korszerủ talajtani tudományának egyik megkülönböztetett jelentőségủ célkitüzése a talajfolyamatok bizonyos célú, irányú és mértékủ szabályozása. Ennek előfeltétele, hogy minél teljesebb és természethübb képünk legyen a talajtulajdonságok térbeli (horizontális és vertikális) variabilitásáról és időbeni dinamizmusáról, valamint ismerjük a végbemenő folyamatok mechanizmusát, befolyásolási lehetőségeit.

\section{Bevezetés}

Az utóbbi években a világ számos országában folynak kutatások a talajok tér-és időbeni variabilitásának minél részletesebb, pontosabb és egzaktabb jellemzésére, kvantifikálására, térbeli megjelenítésére, modellezésére és előrejelzésére, felhasználva a technikai fejlődés nyújtotta korszerü, új lehetőségeket. Nagyon jó összefoglalást nyújt erről a Geoderma címü folyóirat „Új eredmények a kvantitatív talajkészlet felmérésben" címú legutóbbi különszáma (COLLINS et al., 2000), amelyben több mint tíz dolgozat számol be ilyen irányú új tudományos eredményekről, kiindulásként feltéve e koncepció alapkérdéseit:

- Véletlenszerü-e a talajvariabilitás? (WEBSTER, 2000);

- Becsülhetők-e a talajtulajdonságok, előrejelezhetőek-e azok változásai szimulációs modellekkel? (GOOVAERTS, 2000; LAGACHERIE \& VOLTZ, 2000; ODEH \& MCBRATNEY, 2000; BOURENNANE et al., 2000)

A második kérdésre adott igenlő válaszokban a számításba vehető új technikák szinte mindegyikének talajtani alkalmazása megjelent. A geostatisztikai módszerektől kezdve (GROENIGEN, 2000; BOURENNANE et al., 2000), a digitális domborzati és GIS-technika felhasználásán keresztül (LAGACHERIE \& Voltz, 2000; MENDONCA SANTOS et al., 2000; DoBOS et al., 2000) a különböző távérzékelési módszerekig (ODEH \& MCBRATNEY, 2000; DOBOS et al., 
2000; Chaplot et al., 2000, MCBRATNEY et al., 2000), s a forradalmi fejlődés változatlanul tart e területen.

Régóta ismert a szikes talajok, illetve szikes talajú területek különösen nagy tér- és időbeni variabilitása, heterogenitása, viszonylag gyorsan változó mozaikos tarkasága. Ezért a talajok szikesedési állapotának egzakt és kvantitatív jellemzésére, a sófelhalmozódási és szikesedési folyamatok - időben történő megelözését lehetővé tevő - előrejelzésére egyre kiterjedtebben használnak numerikus szimulációt (SIMUNEK \& SUAREZ, 1994; WAGENET \& HUTSON, 1987; ABDEl-DAYEM \& SKagGS, 1990; OOSTERBAAN \& ABU SENNA, 1990; VANDERBORGHT et al., 1997; RHOADES et al., 1989b; KARUCZKA, 1999; BAKACSI \& KUTI, 1998).

\section{A vizsgálatok célja}

Vizsgálataink célja az volt, hogy egy kiválasztott szikes talajú mintaterületen felmérjük a sófelhalmozódás folyamatát meghatározó vagy befolyásoló tényezőket és ezek elemzése alapján a numerikus sófelhalmozódási vizsgálatokhoz megfelelő információkhoz jussunk, mégpedig a mintaterület jellegzetes, legjobban elkülönülő részterületekre történő felosztásával.

Egy adott területen végbemenő sófelhalmozódás szabatos jellemzése csupán véges számú szimulációs futtatással lehetséges. Annak eldöntése, hogy a probléma megoldásához - racionálisan - hány szimuláció szükséges vagy elégséges, szükségessé teszi az alábbi két kérdés megválaszolását:

- a numerikus szimulációhoz hány részre (foltra) osszuk fel a területet, mivel ez szabja meg a numerikusan vizsgált ,szelvények” számát;

- területileg hogyan, mi(k)nek alapján határoljuk el e foltokat?

A mintaterület részletes talajtani jellemzését célzó előzetes vizsgálataink szerint az elemzésre kiválasztott 4 talajszelvény a kémiai tulajdonságok, a szemcseösszetétel és a pF-görbék tekintetében igen hasonló volt. Kiugróan kis hidraulikus vezetőképességet (K-érték) a leginkább szikes talajszelvényben tapasztaltunk. A sófelhalmozódás szempontjából legfontosabb tényezők közül az adott területen a talajfelszín térszíni fekvése, a talaj sótartalma, valamint a talajvízszint terep alatti mélysége és sótartalma mutattak legnagyobb változatosságot. Ezért részletes vizsgálatainkat elsősorban e tényezőkre összpontosítottuk.

\section{Vizsgálati anyag és módszer}

Vizsgálataink első fázisában az adatgyüjtést és az elemzéseket helyszíni terepi megfigyelések alapján hajtottuk végre, majd ezt az információk számítógépes feldolgozása követte. 
A vizsgálatot Karcagtól északra, a „Május 1.” Szövetkezet területén végeztük egy $2,5 \mathrm{~km}$ oldalhosszúságú négyzet alakú területrészen. A vizsgált táblák egy részén évek óta öntöznek és bebizonyosodott, hogy az öntözés következtében időről időre megemelkedő talajvíz a talaj mélyebb rétegeiben e területen is másodlagos sófelhalmozódást okoz (TÓTH \& BLASKÓ, 1998).

A terepi munka során az egymástól mintegy 300 m-re kijelölt transzektek és a mintavételi pontok távolságát lépésszámlálással mértük ki. A mintavételi helyek UTM (Universal Transverse Mercator) koordinátáit kézi müholdas helymeghatározó készülékkel (Garmin eTrex GPS - Global Positioning System) határoztuk meg, ami \pm 15 méteres pontosságot biztosít. Azért használtunk UTM koordinátákat mert az USA-ban gyártott GPS a magyarországi 1:10 000 méretarányú topográfiai térképlapokon feltüntetett EOV koordinátákat nem ismeri.

A mintavételi pontokhoz tartozó térszíni magasságot a terület 1:10 000 méretarányú topográfiai térképéről olvastuk le lineáris interpolációval. Ehhez elötte a mintavételi pontok UTM koordinátáit át kellett számolni EOV (Egységes Országos Vetületi rendszer) koordinátákká. Ehhez a mintaterület 5, a terepen és a térképen egyaránt jól elkülönülö és azonosítható szélső pontját használtuk, amelyre vonatkozóan a terepen meghatároztuk az UTM koordinátákat.

A helyszíni vizsgálatok során helyszíni elektromos vezetőképességmérő müszerrel (Martek SCT 12) három ismétlésben meghatároztuk a talaj 0-40 cm-es rétegének elektromos vezetőképességét $\left(\mathrm{EC}_{\mathrm{a}_{-}} \mathrm{O}-40 \mathrm{~cm}\right)$ és feljegyeztük ezek átlagát. Edelman típusú fúróval talajvízszintig fúrtunk. Közben $50 \mathrm{~cm}$-enként gyüjtöttünk mintákat és a helyszínen meghatároztuk azok elektromos vezetőképességét az alábbiak szerint: $6,2 \mathrm{ml}$ térfogatú kanálban vettünk talajmintát és ahhoz $12,5 \mathrm{ml}$ desztillált vizet adtunk. Az 1:2 térfogatarányú szuszpenziót csomómentesre dolgoztuk és azután mértük meg a szuszpenzió vezetőképességét (EC_0-10 cm stb.). A talajvízszint elérése után feljegyeztük annak mélységét. 15 perc múlva újra regisztráltuk az időközben a felszínhez közelebb emelkedő talajvízszintet. A talajvízből is vettünk mintát és megmértük elektromos vezetőképességét (EC_tviz). Az elektromos vezetőképességet terepi zsebmüszerrel (Horiba) mértük. Bár a nedves talaj vagy a talajpaszta (ill. a talajszuszpenzió) elektromos vezetőképességéből nem lehet közvetlenül egzaktan kiszámítani a talaj sótartalmát (RHOADES et al., 1989a; FILEP, 1999), az EC időbeli és/vagy mélység szerinti változása azonban - adott helyen - arányos a sótartalom változásával. Ezért az általunk vizsgált összefüggések értékeléséhez megfelelőnek tartjuk az egyszerủen és gyorsan mérhető EC értékek használatát.

Az elözetes adatelemzés során az adatok közel normális eloszlást mutattak és a további elemzéshez nem alkalmaztunk adattranszformációt.

A változók közötti összefüggéseket grafikonok készítésével, korrelációs koefficiensek és regressziós egyenletek számításával értékeltük. 
A terepi megfigyelések, mérések és helyszíni

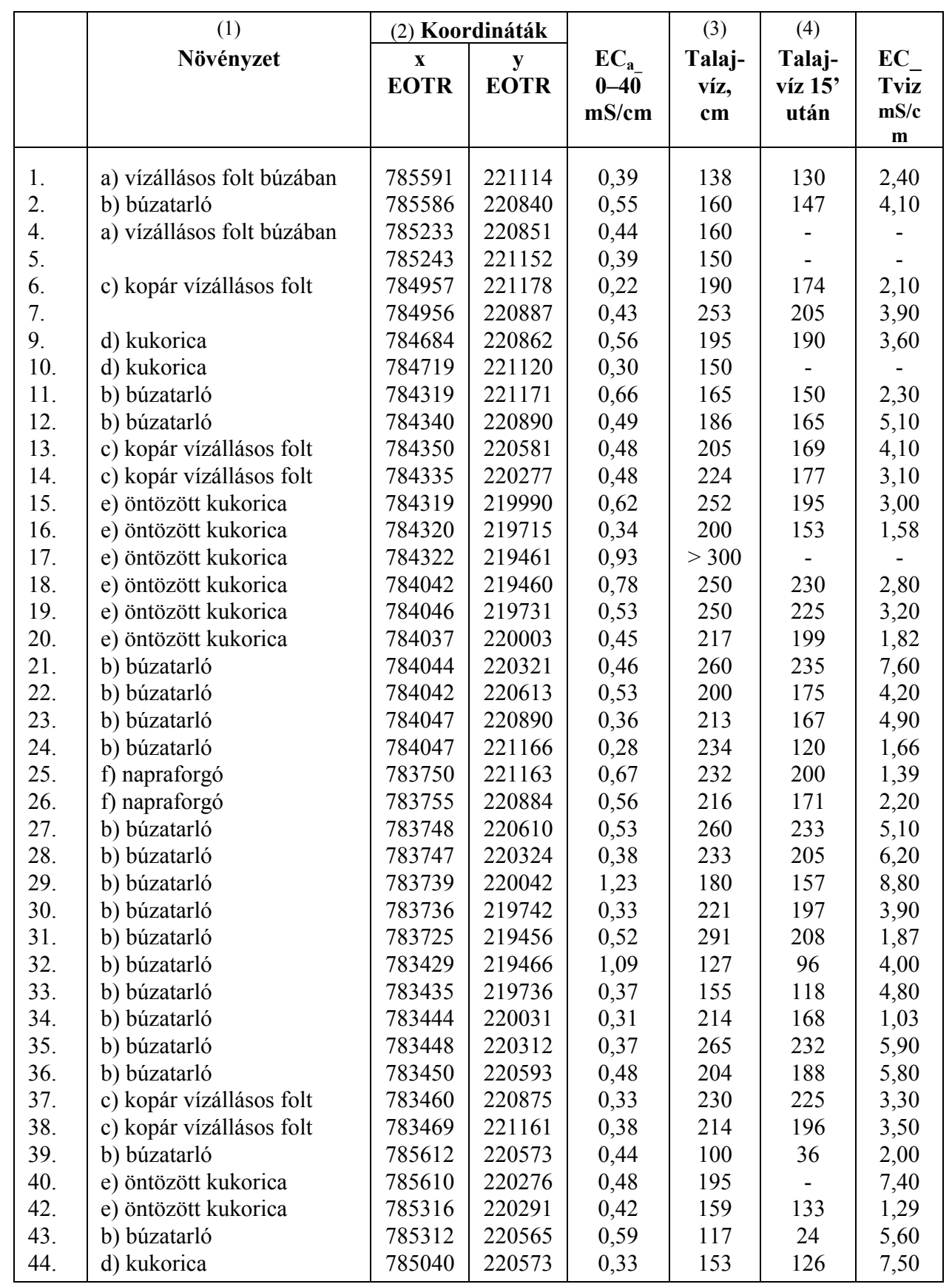


AGROKÉMIA ÉS TALAJTAN Tom. 50. (2001) No. 1-2.

táblázat

vizsgálatok eredményei és statisztikai alapjellemzői

\begin{tabular}{|c|c|c|c|c|c|c|c|}
\hline \multicolumn{6}{|c|}{ EC $\mathrm{mS} / \mathrm{cm}$} & \multirow{2}{*}{$\begin{array}{c}(5) \\
\text { Magas- } \\
\text { ság, } \\
\text { m }\end{array}$} & \multirow{2}{*}{$\begin{array}{c}(6) \\
\text { Cso- } \\
\text { port }\end{array}$} \\
\hline $\begin{array}{c}\text { 0-10 } \\
\mathrm{cm}\end{array}$ & $\begin{array}{c}50-60 \\
\mathrm{~cm}\end{array}$ & $\begin{array}{c}\text { 100-110 } \\
\mathrm{cm}\end{array}$ & $\begin{array}{c}150-160 \\
\mathrm{~cm}\end{array}$ & $\begin{array}{c}200-210 \\
\mathrm{~cm}\end{array}$ & $\begin{array}{c}250-260 \\
\mathrm{~cm}\end{array}$ & & \\
\hline 0,19 & 0,19 & 0,25 & 0,31 & & & 86,5 & 2 \\
\hline 0,15 & 0,27 & 0,18 & 0,50 & & & 87,0 & 2 \\
\hline 0,16 & 0,25 & 0,33 & 0,40 & & & 86,0 & 2 \\
\hline 0,16 & 0,23 & 0,19 & 0,26 & 0,31 & & 86,5 & 2 \\
\hline 0,16 & 0,18 & 0,32 & 0,45 & & & 86,0 & 3 \\
\hline 0,24 & 0,30 & 0,26 & 0,47 & 0,63 & 0,65 & 86,4 & 4 \\
\hline 0,23 & 0,22 & 0,74 & 0,90 & & & 86,5 & 3 \\
\hline 0,27 & 0,36 & 0,66 & 0,91 & & & 86,2 & 2 \\
\hline 0,24 & 0,28 & 0,36 & 0,50 & & & 86,5 & 2 \\
\hline 0,36 & 0,26 & 0,55 & 0,69 & 0,78 & & 86,5 & 3 \\
\hline 0,44 & 0,46 & 0,60 & 0,80 & & & 85,6 & 3 \\
\hline 0,25 & 0,23 & 0,33 & 0,52 & 0,71 & & 86,5 & 3 \\
\hline 0,27 & 0,31 & 0,32 & 0,37 & 0,42 & & 87,5 & 4 \\
\hline 0,29 & 0,26 & 0,27 & 0,37 & 0,47 & & 87,5 & 3 \\
\hline 0,55 & 0,33 & 0,41 & 0,47 & & & 87,7 & 4 \\
\hline 0,24 & 0,40 & 0,40 & 0,50 & 0,50 & & 88,0 & 4 \\
\hline 0,53 & 0,36 & 0,37 & 0,38 & 0,53 & & 87,5 & 4 \\
\hline 0,43 & 0,30 & 0,32 & 0,40 & 0,40 & & 87,8 & 3 \\
\hline 0,26 & 0,40 & 0,72 & 1,18 & 1,48 & 1,54 & 87,0 & 4 \\
\hline 0,47 & 0,44 & 0,62 & 1,00 & 1,17 & & 86,6 & 3 \\
\hline 0,69 & 0,87 & 1,16 & 1,27 & 1,18 & & 86,5 & 3 \\
\hline 0,52 & 0,26 & 0,43 & 0,45 & 0,44 & & 86,0 & 3 \\
\hline 0,28 & 0,20 & 0,39 & 0,36 & 0,52 & & 86,0 & 4 \\
\hline 0,30 & 0,37 & 0,52 & 0,80 & & & 86,0 & 3 \\
\hline 0,40 & 0,36 & 0,39 & 0,77 & 1,02 & & 87,0 & 4 \\
\hline 0,21 & 0,31 & 0,96 & 1,64 & & & 87,0 & 4 \\
\hline 0,83 & 1,26 & 1,29 & 1,70 & 1,43 & & 87,0 & 3 \\
\hline 0,12 & 0,16 & 0,28 & 0,54 & 0,62 & & 87,3 & 3 \\
\hline 0,31 & 0,27 & 0,32 & 0,51 & 0,57 & 0,72 & 88,0 & 4 \\
\hline 0,35 & 0,89 & 0,83 & & & & 86,5 & 2 \\
\hline 0,28 & 0,51 & 1,15 & 1,30 & & & 86,8 & 2 \\
\hline 0,23 & 0,20 & 0,23 & 0,24 & 0,44 & & 87,5 & 3 \\
\hline 0,15 & 0,29 & 1,39 & 1,97 & & & 87,0 & 4 \\
\hline 0,35 & 1,17 & 1,32 & 1,27 & & & 86,5 & 3 \\
\hline 0,44 & 0,33 & 0,68 & 1,02 & 1,04 & & 86,5 & 4 \\
\hline 0,29 & 0,29 & 0,48 & 1,03 & 0,97 & & 86,5 & 3 \\
\hline 0,14 & 0,38 & 0,62 & 0,44 & & & 87,0 & 1 \\
\hline 0,31 & 0,32 & 0,44 & 0,58 & 1,22 & & 87,4 & 3 \\
\hline 0,32 & 0,35 & 0,34 & 0,44 & & & 86,8 & 2 \\
\hline 0,22 & 0,73 & 1,01 & & & & 87,1 & 1 \\
\hline 0,43 & 0,76 & 1,44 & 1,61 & & & 86,8 & 2 \\
\hline
\end{tabular}




\begin{tabular}{|c|c|c|c|c|c|c|c|}
\hline & \multirow{2}{*}{$\begin{array}{c}\text { (1) } \\
\text { Növényzet }\end{array}$} & \multicolumn{2}{|c|}{ (2) Koordináták } & \multirow[b]{2}{*}{$\begin{array}{c}\mathrm{EC}_{\mathrm{a}_{-}} \\
\mathbf{0 - 4 0} \\
\mathrm{mS} / \mathrm{cm}\end{array}$} & \multirow{2}{*}{$\begin{array}{l}(3) \\
\text { Talaj- } \\
\text { víz, } \\
\text { cm }\end{array}$} & \multirow{2}{*}{$\begin{array}{c}(4) \\
\text { Talaj- } \\
\text { víz 15, } \\
\text { után }\end{array}$} & \multirow[b]{2}{*}{$\begin{array}{c}\text { EC } \\
\text { Tviz } \\
\mathrm{mS} / \mathrm{c} \\
\mathrm{m} \\
\end{array}$} \\
\hline & & $\begin{array}{c}\mathbf{x} \\
\text { EOTR }\end{array}$ & $\begin{array}{c}\mathbf{y} \\
\text { EOTR }\end{array}$ & & & & \\
\hline 45. & b) búzatarló & 785037 & 220300 & 0,33 & 165 & 142 & 7,00 \\
\hline 46. & g) tökföld & 783330 & 218904 & 0,51 & 194 & 173 & 2,50 \\
\hline 47. & g) tökföld & 783342 & 219191 & 0,46 & 180 & 153 & 3,50 \\
\hline 49. & b) búzatarló & 783675 & 219196 & 0,35 & 280 & 268 & 2,70 \\
\hline 50. & b) búzatarló & 783674 & 218910 & 0,34 & 280 & 232 & 8,60 \\
\hline 51. & h) öntözött hibridkukorica & 783944 & 218904 & 0,58 & 280 & 240 & 3,70 \\
\hline 52. & h) öntözött hibridkukorica & 783941 & 219172 & 0,61 & 280 & - & - \\
\hline 54. & h) öntözött hibridkukorica & 784241 & 219161 & 0,35 & $>300$ & - & - \\
\hline 55. & h) öntözött hibridkukorica & 784216 & 218899 & 0,64 & 193 & 170 & 2,30 \\
\hline 56. & h) öntözött hibridkukorica & 784567 & 218875 & 0,40 & 234 & 221 & 5,20 \\
\hline 57. & c) kopár vízállásos folt & 784564 & 219167 & 0,56 & 75 & 54 & 1,11 \\
\hline 59. & h) öntözött hibridkukorica & 784867 & 219158 & 0,42 & 196 & 173 & 3,30 \\
\hline 60. & i) lucerna & 785183 & 218888 & 0,33 & $>300$ & - & - \\
\hline 61. & i) lucerna & 785178 & 219175 & 0,40 & $>300$ & - & - \\
\hline 63. & e) öntözött kukorica & 785474 & 219165 & 0,42 & 242 & 231 & 2,60 \\
\hline 64. & e) öntözött kukorica & 785483 & 218883 & 0,55 & 176 & 174 & 2,70 \\
\hline 65. & b) búzatarló & 784647 & 220540 & 0,38 & 154 & 116 & 11,3 \\
\hline 66. & b) búzatarló & 784649 & 220224 & 0,37 & 222 & 168 & 4,70 \\
\hline 67. & h) öntözött hibridkukorica & 784652 & 219924 & 0,38 & 197 & 144 & 3,30 \\
\hline 68. & h) öntözött hibridkukorica & 784655 & 219648 & 0,47 & 160 & 151 & 2,40 \\
\hline 70. & h) öntözött hibridkukorica & 784947 & 219669 & 0,51 & 178 & 165 & 3,40 \\
\hline 71. & c) kopár vízállásos folt & 784941 & 219961 & 0,29 & 189 & 159 & 5,20 \\
\hline 72. & j) öntözött lucerna & 785561 & 219942 & 0,35 & 230 & 200 & 2,90 \\
\hline 73. & j) öntözött lucerna & 785548 & 219634 & 0,34 & 244 & 234 & 2,30 \\
\hline 74. & j) öntözött lucerna & 785231 & 219624 & 0,28 & 193 & 188 & 1,50 \\
\hline 75. & j) öntözött lucerna & 785233 & 219924 & 0,28 & 174 & 141 & 4,40 \\
\hline \multicolumn{2}{|c|}{ k) Esetszám } & & & 67 & 67 & 58 & 59 \\
\hline \multicolumn{2}{|c|}{ 1) Minimum } & & & 0,22 & 75 & 24 & 1,03 \\
\hline \multicolumn{2}{|c|}{ m) Maximum } & & & 1,23 & 300 & 268 & 11,3 \\
\hline \multicolumn{2}{|c|}{ n) Átlag } & & & 0,468 & 208 & 173 & 3,89 \\
\hline \multicolumn{2}{|c|}{ o) Szórás } & & & 0,176 & 50,6 & 48,8 & 2,13 \\
\hline
\end{tabular}

Klaszter-analízis segítségével vizsgáltuk, hogy az adatállományban hány csoport különül el. Mivel négy jól elváló csoport mutatkozott, a következő lépésben az SPSS statisztikai programcsomag „Quick Cluster” algoritmusával (ANDERBERG, 1973) az adatállományt négy maximálisan elváló, viszonylag homogén csoportra osztottuk szét. Az algoritmus elöször meghatározza az adathalmaz többváltozós centroidjait (csoport központjait), majd az egyes megfigyeléseket a hozzájuk legközelebbi centroid csoportjába sorolja be. 
1. táblázat folytatása

\begin{tabular}{|c|c|c|c|c|c|c|c|}
\hline \multicolumn{6}{|c|}{ EC_mS/cm } & \multirow{2}{*}{$\begin{array}{c}(5) \\
\text { Magas- } \\
\text { ság, } \\
\text { m }\end{array}$} & \multirow{2}{*}{$\begin{array}{l}(6) \\
\text { Cso- } \\
\text { port }\end{array}$} \\
\hline $\begin{array}{c}\text { 0-10 } \\
\text { cm }\end{array}$ & $\begin{array}{c}50-60 \\
\mathrm{~cm}\end{array}$ & $\begin{array}{c}100-110 \\
\mathrm{~cm}\end{array}$ & $\begin{array}{c}150-160 \\
\mathrm{~cm}\end{array}$ & $\begin{array}{c}200-210 \\
\mathrm{~cm}\end{array}$ & $\begin{array}{c}250-260 \\
\mathrm{~cm}\end{array}$ & & \\
\hline 0,30 & 0,32 & 0,94 & & & & 86,4 & 2 \\
\hline 0,56 & 0,34 & 0,35 & 0,40 & 0,52 & & 87,0 & 3 \\
\hline 0,42 & 0,38 & 0,46 & 0,69 & & & 86,8 & 3 \\
\hline 0,25 & 0,26 & 0,35 & 0,68 & 0,96 & 1,02 & 88,0 & 4 \\
\hline 0,22 & 0,23 & 0,80 & 1,18 & 1,99 & 2,10 & 87,6 & 4 \\
\hline 0,57 & 0,34 & 0,46 & 0,79 & 1,35 & & 87,3 & 4 \\
\hline 0,40 & 0,37 & 0,60 & 0,61 & 0,65 & & 87,5 & 4 \\
\hline 0,29 & 0,30 & 0,43 & 0,58 & 0,71 & & 87,5 & 4 \\
\hline 0,36 & 0,34 & 0,38 & 0,51 & & & 86,6 & 3 \\
\hline 0,23 & 0,16 & 0,27 & 0,83 & 0,90 & & 87,5 & 4 \\
\hline 0,75 & 0,49 & & & & & 87,5 & 1 \\
\hline 0,17 & 0,32 & 0,38 & 0,43 & & & 87,5 & 3 \\
\hline 0,25 & 0,30 & 0,53 & 1,34 & 1,54 & 1,48 & 87,5 & 4 \\
\hline 0,32 & 0,28 & 0,96 & 1,18 & & & 87,5 & 4 \\
\hline 0,35 & 0,34 & 0,46 & 0,36 & & & 87,5 & 4 \\
\hline 0,23 & 0,38 & 1,19 & 1,26 & & & 87,5 & 3 \\
\hline 0,21 & 1,44 & 2,30 & & & & 86,5 & 2 \\
\hline 0,32 & 0,38 & 0,76 & 1,28 & 1,01 & & 86,7 & 3 \\
\hline 0,28 & 0,25 & 0,31 & 0,65 & 0,72 & & 86,9 & 3 \\
\hline 0,23 & 0,24 & 0,23 & 0,43 & & & 87,2 & 2 \\
\hline 0,27 & 0,26 & 0,29 & 0,48 & & & 87,2 & 3 \\
\hline 0,25 & 0,13 & 0,58 & 0,92 & 0,95 & & 86,5 & 3 \\
\hline 0,18 & 0,20 & 0,44 & 0,78 & & & 86,9 & 3 \\
\hline 0,20 & 0,24 & 0,24 & 0,52 & 0,73 & 0,50 & 87,4 & 4 \\
\hline 0,14 & 0,22 & 0,43 & 0,38 & & & 87,2 & 3 \\
\hline 0,31 & 0,43 & 1,24 & 1,08 & & & 86,6 & 2 \\
\hline 67 & 67 & 66 & 62 & 34 & 7 & 67 & \\
\hline 0,12 & 0,13 & 0,18 & 0,24 & 0,31 & 0,50 & 85,6 & \\
\hline 0,83 & 1,44 & 2,30 & 1,97 & 1,59 & 2,10 & 88,0 & \\
\hline 0,315 & 0,377 & 0,595 & 0,753 & 0,838 & 1,144 & 86,95 & \\
\hline 0,145 & 0,248 & 0,393 & 0,403 & 0,364 & 0,583 & 0,557 & \\
\hline
\end{tabular}

\section{Vizsgálati eredmények és értékelésük}

Terepi méréseink, megfigyeléseink és helyszíni vizsgálataink eredményeit az 1. táblázatban foglaltuk össze.

Az 1. táblázatból kitünik, hogy a vizsgált négyzetben többféle növénykultúra helyezkedett el. A mérési pontok jelentős része 9 vízállásos foltba esett, ami a 2000. év csapadékos tavaszi időjárásának volt a következménye. A mintavételi 
pontok magassága maximum 2,4 m-rel különbözött, ami a Nagykunságban - figyelembe véve a vizsgálati terület kis kiterjedését - jelentősnek tekinthető.

A megütött talajvízszint átlagos terep alatti mélysége 2 méter körüli volt, szintén jelentős különbségeket mutatott (min. $75 \mathrm{~cm}$, max. $300 \mathrm{~cm}$ ). A talajvíz szintje a fúrt lyukban 15 percet követöen átlagosan $35 \mathrm{~cm}-\mathrm{t}$ emelkedett, ami a térség részben nyomás alatt álló talajvizei esetében nem szokatlan jelenség.

A talajvíz átlagos elektromos vezetőképessége nagy volt, mintegy $4 \mathrm{mS} / \mathrm{cm}$, 1-11 mS/cm között váltakozott. A talajban a sófelhalmozódás maximuma a legmélyebb rétegekben mutatkozott, a felszíntől lefelé a talajrétegek átlagos sótartalma fokozatosan növekedett (1. táblázat).

\section{Korrelációs vizsgálatok}

A talaj helyszínen meghatározott elektromos vezetőképessége $\left(\mathrm{EC}_{\mathrm{a}} \_-40\right.$ $\mathrm{cm}$ ) és az egyes talajrétegekből gyüjtött minták talajszuszpenzióban mért elektromos vezetőképessége közötti korrelációs koefficienseket mutatjuk be a 2 . táblázatban.

A bemutatott korrelációs koefficiens értékek kicsik, nem közelítik meg azokat az értékeket, amelyeket ugyanezen müszerrel mért $\mathrm{EC}_{\mathrm{a}}$ és laboratóriumban mért EC értékek között korábban számoltunk (TóTH et al., 1997, 1998). A kevésbé szoros korreláció oka a talajban a vizsgálati időszak (2000. július 17-21.) alatt tapasztalt kis talajnedvesség-tartalom volt. A talaj nedvességtartalma kisebb volt, mint a szabadföldi vízkapacitás, emiatt a talaj sótartalma és az EC_0 $40 \mathrm{~cm}$ közötti összefüggést jelentős véletlenszerü ingadozás terheli.

Szoros összefüggést találtunk a térszíni magasság és a talajvíz „,megütési mélysége" között: minél magasabban fekvő pontban fúrtuk az észlelölyukat, annál nagyobb mélységben értük el a talajvíz szintjét.

\section{2. táblázat}

Összefüggés a talaj helyszínen, múszeresen meghatározott elektromos vezetőképessége $\left(E_{\mathrm{a}}\right)$ és az egyes talajrétegekből gyüjtött minták talajszuszpenziójában mért elektromos vezetőképesség között

\begin{tabular}{|c|c|c|}
\hline Változók & $\begin{array}{c}(2) \\
\text { Pearson-féle korrelációs } \\
\text { koefficiens }\end{array}$ & $\begin{array}{c}(3) \\
\text { Esetszám }\end{array}$ \\
\hline $\mathrm{EC}_{\mathrm{a}}-\mathrm{EC} \_0-10 \mathrm{~cm}$ & $0,430^{* *}$ & 67 \\
$\mathrm{EC}_{\mathrm{a}}-\mathrm{EC} 50-60 \mathrm{~cm}$ & $0,389^{* *}$ & 67 \\
$\mathrm{EC}_{\mathrm{a}}-\mathrm{EC} \_0-60 \mathrm{~cm}$ & $0,475^{* *}$ & 67 \\
\hline
\end{tabular}

**: a korreláció 0,05 szinten szignifikáns 
A talajvíz elektromos vezetőképessége (EC) szoros kapcsolatot mutatott a felette elhelyezkedő talajrétegek EC értékével (1. ábra). Az 1. ábra csak azokat az eseteket mutatja, amikor a talajszelvényt $0-250 \mathrm{~cm}$-ig folyamatosan megmintáztuk. Mivel ilyen mélységig csak hét esetben jutottunk, az ábrán csak ezt a 7 esetet tüntettük fel.

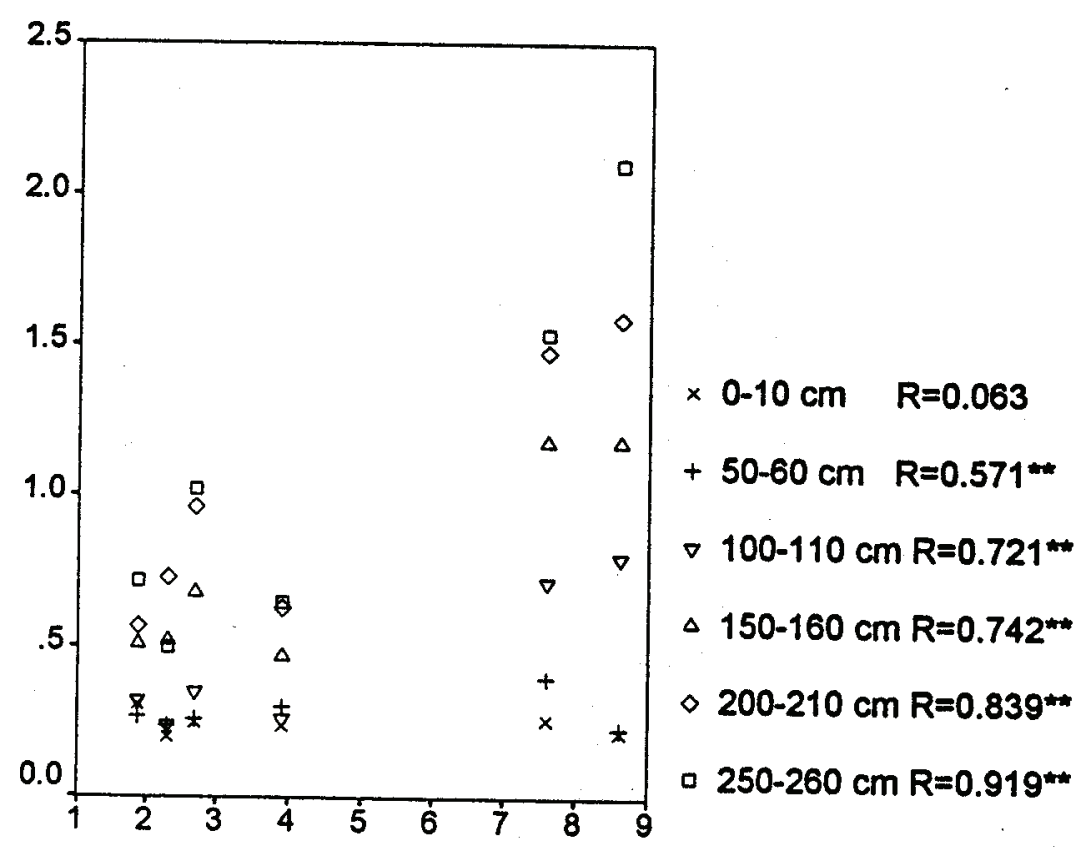

\section{1. ábra}

Összefüggés a talajvíz és a felette különböző mélységben elhelyezkedö talajrétegek elektromos vezetőképessége (EC) között. Vízszintes tengely: A talajvíz EC értéke, $\mathrm{mS} / \mathrm{cm}$. Függőleges tengely: A talajrétegek EC értéke, $\mathrm{mS} / \mathrm{cm}$

Az 1. ábrán feltüntetett korrelációs koefficiensek a feltalaj esetén 59, míg a legnagyobb mélység esetén 6 megfigyelés-párhoz tartoznak. Megállapítható, hogy a talajvízszinthez közeli rétegek sótartalmát a talajvíz statisztikailag szignifikáns mértékben befolyásolja. Növekvő sótartalom a talajvízben növekvő altalaj-sótartalommal jár együtt. A hatás a talajvízszinttől felfelé csökkenő mértékü, a talajvízszint felett $2 \mathrm{~m}$-rel elhelyezkedő réteg EC értéke esetén összefüggés már nem mutatható ki. Ebben az esetben $2 \mathrm{~m}$ a ,kritikus talajvizszint”. 
Regressziós vizsgálatok

Kétváltozós lineáris lépcsőzetes regressziós egyenlettel vizsgáltuk, hogy melyek a talaj gyökérzónájának elektromos vezetőképességét befolyásoló tényezők.

Egyenletünkben a befolyásoló tényezők a talajvíz felszín alatti mélysége (T) és a talajvíz elektromos vezetőképessége (EC_tvíz) volt:

$$
\begin{gathered}
\text { EC_50-60 cm }=0,418+0,07514 \cdot E C \_ \text {tviz }-0,00184 \cdot \text { Tvízszint } 15 \text { ' után } \\
\mathrm{R}^{2}=0,467
\end{gathered}
$$

Minél kisebb tehát a talajvízszint terep alatti mélysége és minél nagyobb a talajvíz elektromos vezetőképessége, annál nagyobb a gyökérzóna elektromos vezetőképessége is. Ez irányú adatainkat mutatjuk be az 1. ábrán. Ez az eredmény teljes összhangban van 'SIGMOND (1923), ARANY (1956), KOVDA és SZABOLCS (1979), SZABOLCS (1979), SzABOLCS és munkatársai (1969) és VÁRALLYAY (1974) korábbi megállapításaival, valamint TÓTH és KUTI (1999a,b) egy hortobágyi mintaterületre vonatkozóan levont következtetéseivel.

\section{Klaszter-analizis}

A 3. táblázatban a számított klaszter-központokat foglaltuk össze. A 4 csoport a varianciaanalízis alapján a talajvízszint terep alatti mélysége, a talajfelszín térszíni magassága és az 50-60 cm-es réteg EC-je szerint szignifikánsan eltér egymástól.

Az 1. csoporttól a 4. csoportig a talajvízszint terep alatti mélysége nő, az 50$60 \mathrm{~cm}$-es réteg sótartalma csökken. A 2. csoporttól a 4. csoportig nö a térszíni magasság.

\section{3. táblázat}

A klaszter-analízissel szétválasztott klaszter-központok csoportátlagai

\begin{tabular}{|l|c|c|c|c|}
\hline \multicolumn{1}{|c|}{ Jellemzők } & \multicolumn{4}{|c|}{ (2) Csoportok } \\
\cline { 2 - 5 } & $\mathbf{1 .}$ & $\mathbf{2 .}$ & $\mathbf{3 .}$ & $\mathbf{4 .}$ \\
\hline $\mathrm{EC}_{\mathrm{a}}$ 0-40 cm, mS/cm & 0,53 & 0,46 & 0,45 & 0,49 \\
a) Megütött talajvíz, cm & 97,33 & 155,00 & 202,00 & 264,36 \\
b) Talajvízszint 15 perc után & 38,00 & 131,82 & 171,59 & 224,65 \\
EC_tvíz, mS/cm & 2,90 & 4,68 & 3,57 & 4,08 \\
EC_0-10 cm, mS/cm & 0,37 & 0,26 & 0,34 & 0,32 \\
EC_50-60 cm, mS/cm & 0,53 & 0,47 & 0,37 & 0,30 \\
EC_100-110 cm, mS/cm & 0,82 & 0,75 & 0,55 & 0,53 \\
c) Magasság, m & 87,20 & 86,59 & 86,80 & 87,31 \\
\hline
\end{tabular}


Az 1. csoport csupán 3 esetet tartalmaz, ezek kiugró viselkedésủek, szélsőségesen magas talajvízszint jellemzi őket és ennek következtében a talaj sótartalma is ebben a csoportban a legnagyobb.

A 2. ábra a talajfelszín térszíni magasságát mutatja a vizsgálati pontokon. Az ábra szerint a magasság egyenletesen változik a mintaterületen, kivéve a legalacsonyabb pont környékét, ami egy vízállásos rész, feltehetően egy valamikori folyómeder.

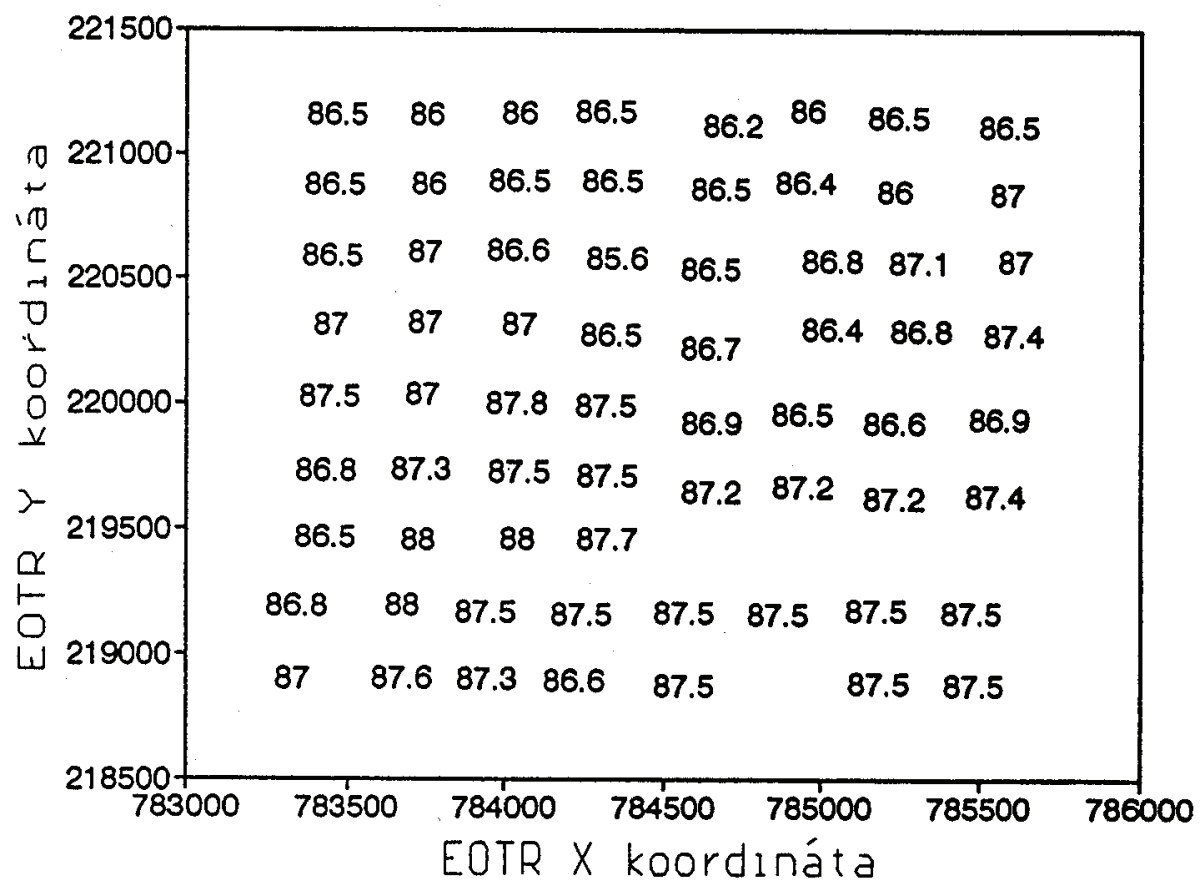

2. ábra

A mintavételi pontok talajfelszínének térszíni magassága

A 3. ábra jól mutatja, hogy a területen a klaszterelemzéssel besorolt helyek összefüggő foltokat alkotnak. A változók többdimenziós terében elvégzett csoportosítás eredményét a felszín két, a csoportosítás során figyelembe nem vett dimenziója szerint felrajzolva jól elváló egységeket különíthettünk el. A jelenleg - nemzetközi együttmüködésben - folyó kutatásaink során numerikus szimulációval ezekre a foltokra fogjuk előrejelezni a sófelhalmozódás mértékét. 


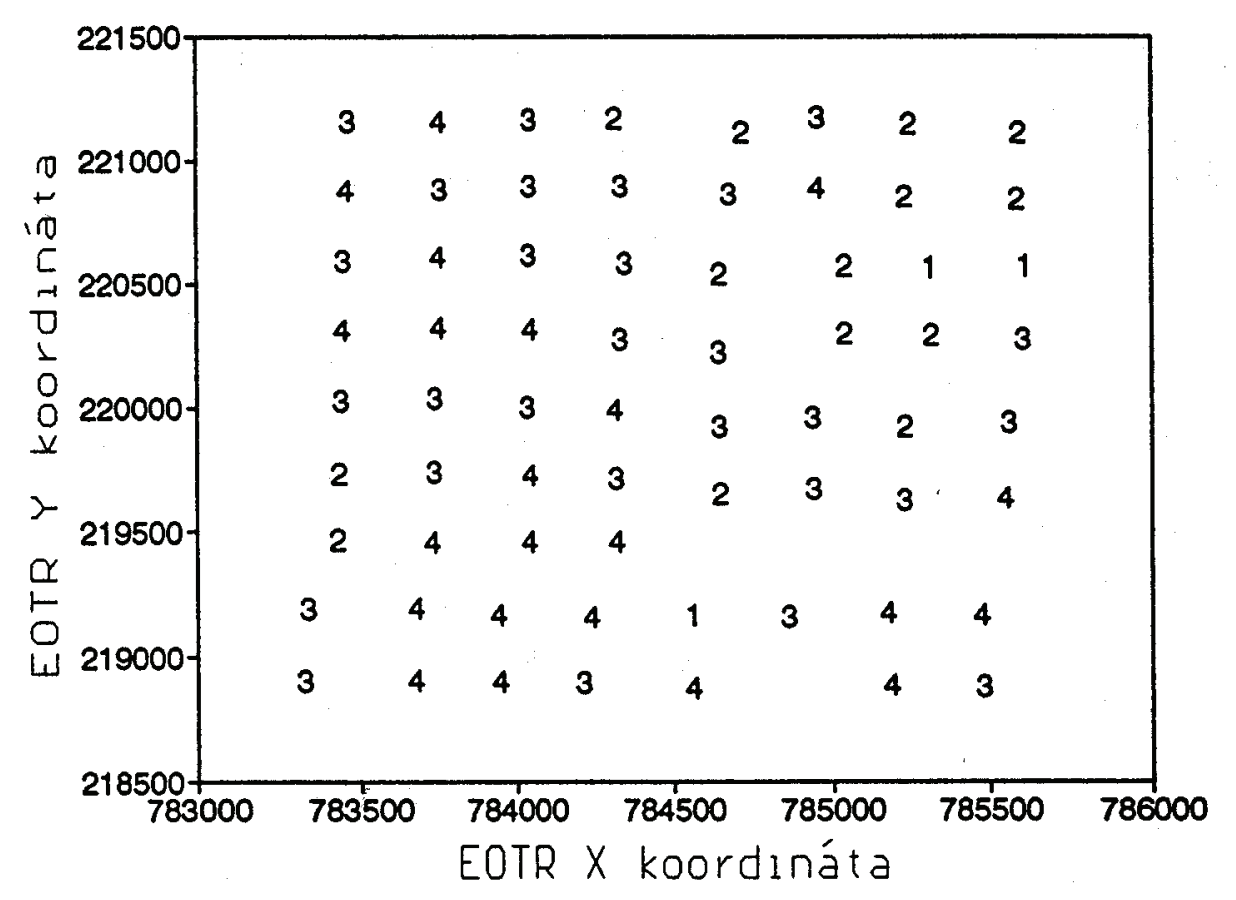

3. ábra

A mintaterületen elkülönített csoportok térbeli megoszlása

\section{Összefoglalás}

Egy nagykunsági $2,5 \times 2,5 \mathrm{~km}$-es terület 67 pontján helyszíni vizsgálatok alapján jellemeztük és elemeztük a talajok sófelhalmozódásának tényezőit. A vizsgálat célja egymástól különböző, de homogén foltok elkülönítése volt, amelyeken a sófelhalmozódás numerikus szimulációval vizsgálható.

Igazoltuk, hogy minél magasabb volt a talajfelszín térszíni fekvése, annál nagyobb volt a talajvízszint terep alatti mélysége. A talajvízszint felett elhelyezkedő talajrétegek sótartalma egyenes arányban állt a talajvíz sótartalmával (elektromos vezetőképességével).

A „Quick Cluster” algoritmus alkalmazásával a változók többdimenziós terében négy csoportot különítettünk el. A csoportok elválásában a legfontosabb változók, a sófelhalmozódás szempontjából fontos talajvízmélység, térszíni magasság és az 50-60 cm-es réteg sótartalma voltak. A csoportok a terület térképén jól elváltak és a jövőben ezekben végezzük a sófelhalmozódás numerikus szimulációval történő előrejelzését. 
A munkát az Európai Közösség Környezeti és Éghajlati Kutatási Programja (PL970598 sz. pályázat, szerződésszám ENV4-CT97-0681), a publikálást részben az OTKA T 023271 és T 030739 számú pályázatok támogatták.

\section{Irodalom}

ABDEL-DAYEM, S. \& SKAGGS, R. W., 1990. Extension of DRAINMOD for simulating water management in arid regions. In: Symposium on Land Drainage for Salinity Control in Arid and Semi-Arid Regions, Cairo, February 25-March 2. Vol. 2. 201-212.

Anderberg, M. J., 1973. Cluster Analysis for Applications. Academic Press. New York.

ARANY S., 1956. A szikes talaj és javítása. Mezőgazd. Kiadó. Budapest.

BAKACSI, Zs. \& KUTI, I., 1998. Agrogeological investigation on a salt affected landscape in the Danube Valley, Hungary. Agrokémia és Talajtan. 47. 129-138.

BourennANe, H., King, D. \& Couturier, A., 2000. Comparison of kriging with external drift and simple linear regression for predicting soil horizon thickness with different sample densities. In: Developments in Quantitative Soil Resource Assessment (PEDOMETRICS '98). (Eds.: Collins, M. et al.) Geoderma. Special Issue. 97. (3-4) 255-272.

Chaplot, V., WALTER, C. \& CURMI, P., 2000. Improving soil hydromorphy prediction according to DEM resolution and available pedological data. In: Developments in Quantitative Soil Resource Assessment (PEDOMETRICS '98). (Eds.: Collins, M. et al.) Geoderma. Special Issue. 97. (3-4) 405-422.

Collins, M. et al. (Eds.), 2000. Developments in Quantitative Soil Resource Assessment (PEDOMETRICS '98). Geoderma. Special Issue. 97. (3-4) 147-424.

Doвos, E. et al., 2000. Use of combined digital elevation model and satellite radiometric data for regional soil mapping. In: Developments in Quantitative Soil Resource Assessment (PEDOMETRICS '98). (Eds.: Collins, M. et al.) Geoderma. Special Issue. 97. (3-4) 367-392.

FILEP Gy., 1999. A szikes talajok kémiai jellemzői közötti összefüggések. Agrokémia és Talajtan. 43. 419-430.

GoovaERTS, P., 2000. Estimation or simulation of soil properties? An optimization problem with conflicting criteria. In: Developments in Quantitative Soil Resource Assessment (PEDOMETRICS '98). (Eds.: COLLINS, M. et al.) Geoderma. Special Issue. 97. (3-4) 165-186.

Groenigen, J. W. VAN, 2000. The influence of variogram parameters on optimal sampling schemes for mapping by kriging. In: Developments in Quantitative Soil Resource Assessment (PEDOMETRICS '98). (Eds.: Collins, M. et al.) Geoderma. Special Issue. 97. (3-4) 223-236.

KARUCZKA A., 1999. Időjárási viszonyok hatása a szikes talaj sómérlegére. Agrokémia és Talajtan. 48. 459-468. 
Kovda, V. A. \& SzabolcS, I. (Eds.), 1979. Modelling of Soil Salinization and Alkalization. Agrokémia és Talajtan. 28. (Suppl.) 1-208.

Lagacherie, P. \& Voltz, M., 2000. Predicting soil properties over a region using sample information from a mapped reference area and digital elevation data: a conditional probability approach. In: Developments in Quantitative Soil Resource Assessment (PEDOMETRICS '98). (Eds.: ColLINS, M. et al.) Geoderma. Special Issue. 97. (3-4. 187-208.

McBratney, A. B., Bishop, T. F. A. \& Teliatnikov, I. S., 2000. Two soil profile reconstruction techniques. In: Developments in Quantitative Soil Resource Assessment (PEDOMETRICS '98). (Eds.: Collins, M. et al.) Geoderma. Special Issue. 97. (3-4) 209-222.

MENDONCA SANTOS, M. L. et al., 2000. Three-dimensional GIS cartography applied to the study of the spatial variation of soil horizon in a Swiss floodplain. In: Developments in Quantitative Soil Resource Assessment (PEDOMETRICS '98). (Eds.: Collins, M. et al.) Geoderma. Special Issue. 97. (3-4) 351-366.

Odeh, I. O. A. \& MCBRATNEY, A. B., 2000. Using AVHRR images for spatial prediction of clay content in the lower Namoi Valley of Eastern Australia. In: Developments in Quantitative Soil Resource Assessment (PEDOMETRICS '98). (Eds.: Collins, M. et al.) Geoderma. Special Issue. 97. (3-4) 209-222.

OosterbaAn, R. J. \& ABU SenNa, M., 1990. Drainage and salinity predictions in the Nile delta, using SALTMOD. In: Symposium on Land Drainage for Salinity Control in Arid and Semi-Arid Regions, Cairo, February 25-March 2. Vol. 1. 274 286.

RHOADES, J. D. et al., 1989a. Estimating soil salinity from saturated soil-paste electrical conductivity. Soil Sci. Soc. Am. J. 53. 428-433.

RHOADES, J. D. et al., 1989b. Determining soil salinity for soil and soil-paste electrical conductivities: sensitivity analysis of models. Soil Sci. Soc. Am. J. 53. 1368 1374.

'SigmOND E., 1923. A hazai szikesek és megjavítási módjaik. Magyar Tudományos Akadémia. Budapest.

SimUNEK, J. \& SUAREZ, D. L., 1994. Two-dimensional transport model for variably saturated porous media with major ion chemistry. Water Resources Research. 30. $1115-1133$.

SzABOLCS, I., 1979. Review of Research on Salt Affected Soils. Natural Resources Research. XV. UNESCO. Paris.

SzabolCs I., DARAB K. \& VÁrallyay Gy., 1969. A tiszai öntözörendszerek és a Magyar Alföld talajainak termékenysége a Kiskörei Öntözörendszer által érintett területen. II. A talajvíz „kritikus” mélysége a kiskörei öntözörendszer által érintett területen. Agrokémia és Talajtan. 18. 211-220.

TóтH, T. \& BLASKó, L., 1998. Secondary salinization caused by irrigation. In: The Soil As a Strategic Resource: Degradation Processes and Conservation Measures. (Eds.: Rodriguez, Rodriguez A., Jiménez MendozA, C. C. \& Tejedor SALGUERO, M. I.) 229-253. Geoforma Ediciones, Logrono.

То́тн T. \& KUTI L., 1999a. Összefüggés a talaj sótartalma és egyes földtani tényezők között a hortobágyi „Nyírőlapos” mintaterületen. 1. Általános földtani jellemzés, 
a felszín alatti rétegek kalcittartalma és pH értéke. Agrokémia és Talajtan. 48. $431-444$.

TóTH T. \& KUTI L., 1999b. Összefüggés a talaj sótartalma és egyes földtani tényezők között a hortobágyi „Nyírőlapos” mintaterületen. 2. Többszörös összefüggések és a felszíni sótartalom becslése. Agrokémia és Talajtan. 48. 445-457.

TÓTH, T., KerTÉSz, M. \& PÁSzTOR, L., 1998. New approaches in salinity-sodicity mapping in Hungary. Agrokémia és Talajtan. 47. 76-85.

TóтH, T. et al., 1997. Plant composition of a pasture as a predictor of soil salinity. Rev. Biol. Trop. 45. 1385-1393.

VANDERBORGHT, J. et al., 1997. Analysis of solute redistribution in heterogeneous soil: II. Numerical simulation of solute transport. In: geoENVI - Geostatistics for Environmental Applications. (Eds.: SOARES, A., GómEZ-HERnÁNDEZ, J. \& FroideVAuX, R.) 283-295. Kluwer Academic Publ. Dordrecht.

VÁRALlyAy, Gy., 1974. Hydrophysical aspects of salinization from the groundwater. Agrokémia és Talajtan. 23. (Suppl.) 29-44.

WAGENET, R. J. \& HuTSON, J. L., 1987. LEACHM, Leaching estimation and chemistry model: A process based model of water and solute movement, transformations, plant uptake and chemical reactions in the unsaturated zone. Continuum Vol. 2. Water Resources Institute, Cornell University, Ithaca, NY.

WEBSTER, R., 2000. Is soil variation random? In: Developments in Quantitative Soil Resource Assessment (PEDOMETRICS '98). (Eds.: COLlins, M. et al.) Geoderma. Special Issue. 97. (3-4) 149-164.

Érkezett: 2000. október 24. 


\title{
Variability in the Soil of a Sample Area According to Salt Accumulation Factors
}

\author{
T. TÓTH and G. VÁRALLYAY \\ Research Institute for Soil Science and Agricultural Chemistry of the \\ Hungarian Academy of Sciences, Budapest
}

\begin{abstract}
Summary
Soil salt accumulation factors were characterized and analyzed on the basis of onsite examinations at 67 points of a $2.5 \times 2.5 \mathrm{~km}$ area in the Nagykunság region of Hungary. The aim of the study was to distinguish homogeneous patches which differed from each other and on which the numerical simulation of salt accumulation could be tested.

It was confirmed that the higher the soil surface lay, the greater was the depth of the groundwater below the area. The salt content of the soil layers above the groundwater level was directly proportional to the salt content (electrical conductivity) of the groundwater. Using the "Quick Cluster" algorithm four groups could be distinguished in the multidimensional space of the variables. The most important variables in distinguishing the groups from the point of view of salt accumulation were the depth of the groundwater, the height of the relief and the salt content of the $50-60 \mathrm{~cm}$ layer. The groups were quite distinct on the area map and will be used in the future to predict salt accumulation by means of numerical simulation.

Table 1. Results of on-site observations, measurements and analyses, and basic statistical parameters. (1) Vegetation. a) patch of standing water in wheat, b) wheat stubble, c) bare patch of standing water, d) maize, e) irrigated maize, f) sunflower, g) marrow field, h) irrigated hybrid maize, i) alfalfa, j) irrigated alfalfa, k) case number, 1) minimum, m) maximum, n) mean, o) standard deviation. (2) Coordinates. (3) Groundwater level found. (4) Groundwater after 15 minutes. (5) Height. (4) Group.

Table 2. Correlation between the bulk electrical conductivity $\left(\mathrm{EC}_{\mathrm{a}}\right)$ of the soil determined instrumentally on site and the electrical conductivity measured in soil suspensions of samples collected from various soil layers. (1) Variables. (2) Pearson's correlation coefficient. (3) Case number. Átlag=Mean. ${ }^{* *}$ Correlation significant at 0.05 level.

Table 3. Group means for the cluster centroids separated by means of cluster analysis. (1) Variables. a) Groundwater level found, $\mathrm{cm}, \mathrm{b}$ ) groundwater level after 15 min, c) height, m. (2) Groups.

Fig 1. Correlation between the electrical conductivity (EC) of the groundwater and of the soil layers situated above the groundwater at various depths. Horizontal axis: EC of the groundwater $(\mathrm{mS} / \mathrm{cm})$. Vertical axis: EC of the soil layers $(\mathrm{mS} / \mathrm{cm})$.

Fig. 2. Relief height of the soil surface at the sampling points. Horizontal axis: EOTR $\mathrm{x}$ coordinate. Vertical axis: EOTR y coordinate. EOTR $=$ Uniform National Mapping System.
\end{abstract}

Fig. 3. Spatial distribution of the groups distinguished on the sampling area. Horizontal and vertical axis: see Fig. 2. 